\title{
IMPACT OF THE EU SUCCESSION REGULATION ON STATUTORY INHERITANCE
}

\section{Abstract}

The new EU Succession Regulation has caused a series of controversies. Doubts are linked, inter alia, to the application, as a result of the Regulation, of national laws, which in many places differ from each other. One such area is statutory inheritance. Diverging national rules may result in unsatisfactory consequences of the application of the Regulation. The paper presents this area and looks for a solution that could be applied in the future. According to the author, such a solution is necessary and will allow further integration of the EU succession law.

Keywords

succession - inheritance - Regulation 650/2012 - statutory inheritance - EU

\section{INTRODUCTION}

The 17 August 2015 is the date from which major changes of transborder scope apply to succession. The provisions of Regulation (EU) No 650/2012 of the European Parliament and of the Council of 4 July 2012 on jurisdiction, applicable law, recognition and enforcement of decisions and acceptance and enforcement of authentic instruments in matters of succession, and on the creation of a European Certificate of Succession,

* Professor at Andrzej Frycz Modrzewski Kraków University, Poland, Head of the Institute of Private Law, e-mail: mzalucki@afm.edu.pl 
apply to the deceased starting from that date ${ }^{1}$. The provisions significantly depart from the previous regulations in that regard, which apply to but are not limited to the criterion of citizenship of the deceased as the one element indicating the jurisdiction and governing law of the respective succession case, as applied by many European countries ${ }^{2}$. Owing to the fact that the new regulation comprises all of the Civil Law aspects of trans-border succession of the estate of the deceased ${ }^{3}$, the provisions of the regulation form the basis for indicating the court in one of the EU member states as the one competent to resolve the respective succession case, and identify which domestic substantive law applies in resolving that case.

Against that background a series of controversies arises in relation to the varied standards in that regard which are binding in the particular member states ${ }^{4}$. As it is generally known, the succession law systems of the particular European countries differ from each other, sometimes significantly. Despite that, the European legislator decided to accept a uniform solution, which - as may be expected - is a step towards further integration of the succession law in Europe ${ }^{5}$. Despite opposing voices, integration seems to be probable, even in the near future, because of the unsatisfactory results of the practical application of Regulation No. 650/2012. One of such areas raising doubts and leading to many misunderstandings, and, thus, requiring future unification in Europe, is statutory succession. The influence of Regulation No. 650/2012 on the domestic law is in that regard significant and in many cases surprising. Therefore, the object of this article will be an attempt to determine how the provisions of Regulation No. 650/2012 impact national succession laws as regards statutory succession, and to explain why this may prove to be unsatisfactory.

${ }^{1}$ Official Journal of the European Union of 27.07.2012, No. L 201/107.

2 J. Fitchen, "Recognition”, Acceptance and Enforcement of Authentic Instruments in the Succession Regulation, "Journal of Private International Law" 2012, No. 2, p. 323 et seq.

${ }^{3}$ P. Lagarde, Présentation du règlement sur les successions, [in:] Droit Européen des successions internationals. Le règlement du 4 juliet 2012, G. Kheirallah, M. Revillard (eds.), Paris 2013, p. 5 et seq.

${ }^{4}$ See, for example, M. Załucki, New Revolutionary European Regulation on Succession Matters - Key Issues and Doubts, Revista de Derecho Civil 2016, No. 1, pp. 165-176.

${ }^{5} \mathrm{P}$. Lagarde, Les principes de base du nouveau du règlement européen sur les successions, “Revue Critique de Droit International Privé" 2012, No. 11-12, pp. 691-732. 


\section{SCOPE OF THE REgulation}

Regulation No. 650/2012 is a legal act which comprehensively regulates the issues of the international succession law of the European Union. As provided in Recital 9 and in Article 3.1.a) of the Regulation, this covers "all civil-law aspects of succession to the estate of a deceased person, namely all forms of transfer of assets, rights and obligations by reason of death, whether by way of a voluntary transfer under a disposition of property upon death or a transfer through intestate succession"6. According to the very title of the Regulation, the area of jurisdiction, applicable law, acceptance and enforcement of adjudications, acceptance and enforcement of official documents regarding succession, as well as the new European instrument for documenting the right to inheritance (the European Certificate of Succession) must be considered ${ }^{7}$.

One of the basic tasks of Regulation No. 650/2012 is to identify the legal system applicable to legal succession in reference to a deceased person, called the "succession statute" 8 . The Regulation covers, therefore, the standards separating the areas of operation of the systems of the particular countries in succession law relationships, by determination of which of the systems is to be applied in the respective succession case. The underlying principle of the Regulation is prevention of the inheritance from being divided and, thus, the application of many succession statutes as a result of the parallel use of two or more links of the given case with the specific domestic succession law system. In that regard the Regulation introduces the place of habitual residence of the testator at the time of death as a set of standards to identify the proper legal system applicable to the legal assessment of the specific succession case ${ }^{9}$. Pursuant to Article 21 of the Regulation, the principle that "the law applicable to the succession

${ }^{6}$ Zob. M. Pazdan, Zakres zastosowania rozporzadzenia spadkowego [Scope of Application of the Succession Regulation], [in:] Nowe europejskie prawo spadkowe [A New European Law on Succession], M. Pazdan, J. Górecki (eds.), Warszawa 2015, pp. 24-25.

7 M. Schauer, Europäisches Nachlasszeugnis, [in:] Europäische Erbrechtsverordnung, M. Schauer, E. Scheuba (eds.), Wien 2012, pp. 73-98.

${ }^{8}$ I. Rodríguez-Uría Suárez, La ley aplicable a las sucesiones mortis causa en el Reglamento (UE) 650/2012, “InDret” 2013, No. 2, pp. 2-58.

9 Cf. C. Fischer-Czermak, Anwendungsbereich, [in:], Europäische Erbrechtsverordnung, 
as a whole shall be the law of the State in which the deceased had his habitual residence at the time of death" applies. To that law most of the matters regarding inheritance are subordinated, which include, but are not limited to, the determination of beneficiaries, their shares and duties which could have been imposed on them by the deceased, as well as determination of other succession rights, including the rights to inheritance by the surviving spouse or partner ${ }^{10}$.

Apart from the determination of the succession statute, the Regulation provisions indicate the jurisdiction of courts in succession cases (Articles 4-19 of Regulation No. 650/2012 $)^{11}$. This refers to the jurisdiction of the courts of a member state of the European Union bound by the Regulation. Also in that regard, the Regulation refers to the place of habitual residence of the testator at the time of death. The EU legislator assumed in that regard that the court having jurisdiction with reference to a succession case should, in principle, follow the law of the respective country. Therefore, the Regulation determines not only the succession statute (ius), but also the court of one of the countries as competent to hear the respective succession case (forum). The provisions of the Regulation have been constructed in such a way as to "ensure that the authority dealing with the succession will, in most situations, be applying its own law" (Recital 27). In such situation the ius and the forum coincide, which is particularly important in practice, as it facilitates adjudication in the specific cases. This means that the succession jurisdiction of the courts of a specific member state post 17 August 2015 results, in principle, from the provisions of the Regulation ${ }^{12}$. The court competent with regard to

supra note 5, pp. 23-28; E.M. Bajons, Internationale Zuständigkeit und anwendbares Recht in Erbsachen, [in:] Europäische Erbrechtsverordnung, supra note 5, pp. 29-41.

${ }^{10} \mathrm{M}$. Atallah, The Last Habitual Residence of the Deceased as the Principal Connecting Factor in the Context of the Succession Regulation (650/2012), "Baltic Journal of European Studies" 2015, No. 2, pp. 130-146.

${ }^{11}$ H. Dörner, Die internationale Zuständigkeit zur Ausstellung eines deutschen Erbscheins Zugleich Anmerkungen zum Beschl. des KG v. 10.1.2017 - 6 W 125/16, Deutsche NotarZeitschfirt 2017, pp. 407-417.

${ }^{12}$ Cf. A. Wysocka-Bar, Jurysdykcja krajowa sądów polskich a kolizyjna jednolitość spadku [National Jurisdiction of the Polish Courts and Uniformity of Inheritance], "Problemy Współczesnego Prawa Międzynarodowego, Europejskiego i Porównawczego" 2016, No. 14, p. 90. 
the rule of the latest place of residence of the testator should, therefore decide, based on the law of that place, who and on what principles is named an heir of the deceased person, among other things.

\section{StATUTORY INHERITANCE IN EUROPEAN COUNTRIES}

The basis for succession (and the exact naming of somebody as an heir) is usually the will of the testator, most frequently expressed in the statement of will or by the applicable legal regulations (this also depends on the possible consideration by the legislator of the so-called inheritance agreements and the determination of their place within the legal system). Therefore, testate inheritance and statutory inheritance are basically distinguished. Statutory inheritance applies when the deceased has not drawn up a valid will, or none of the persons named in the will may, or wants to, be an heir. In such a case the binding law must explicitly determine, and \{will determine the circle...?\} determines the circle of heirs as well as the order and proportion of statutory inheritance ${ }^{13}$. The legal provisions regulating statutory succession are present in all countries in the world. Even the common law countries, which are often thought to be the ones in which many legal areas are not codified, have their statutory regulations applicable to statutory succession. Therefore, it is the legal act that determines the order of succession in case the testator has not drawn up a will, or when succession applies otherwise. And this is exactly the point where doubts appear on the background of the provisions of Regulation No. 650/2012. Before 17 August 2015 the domestic succession law, as considered by the legislation of many countries, applied a link between the citizenship of the deceased and the legal system of that country ${ }^{14}$, whereas starting from that date, the link no longer applies to the adjudications on the acquisition of

${ }^{13}$ M. Załucki, Inheritance Law in the Republic of Poland and Other Former Eastern Bloc Countries: Recodification of the Circle of Statutory Heirs, "Electronic Journal of Comparative Law" 2010, No. 2, pp. 1-8.

${ }^{14}$ F.M. Wilke, Das internationale Erbrecht nach der neuen EU-Erbrechtsverordnung, "Recht der Internationalen Wirtschaft" 2012, No. 9, p. 604 et seq. 
inheritance benefits by the heirs of the deceased ${ }^{15}$. In the light of Article 21 of the Regulation, the applicable law is that of the latest place of habitual residence of the testator. The difference is visible particularly in trans-border relationships. For example, if a Polish citizen has a place of habitual residence in Germany, the law applicable to the resolution of their succession case will be the German law, instead of the Polish law that applied before the introduction of the Regulation provisions. This may, and does, raise doubts with regard to the different provisions of domestic succession law, including those applicable to statutory inheritance, i.e. those based on which the heirs are statistically most frequently named in the EU countries.

In the context of the above, it must be indicated that the acts which currently refer to statutory succession in the particular European countries are mainly Civil Codes. They regulate particularly the circle of heirs and the order of their inheritance ${ }^{16}$. Pursuant to the regulations binding in Poland (Articles 931-935 of the Civil Code), the act names first of all the children of the testator (or further descendants) and the spouse as the heirs. Secondly, in the absence of descendants, the spouse and the parents are named heirs by the statute. If one of the parents dies before opening the inheritance, the share applicable to him/her passes to the siblings of the testator. If one of the siblings dies before opening the inheritance but their descendants survive, the share applicable to them passes to the descendants. Thirdly, in the absence of descendants, spouses, parents, siblings, and descendants of the siblings, the whole inheritance falls to the grand-parents of the testator. If any of the grand-parents dies before opening the inheritance, the share applicable to them falls to their descendants. Fourthly, in the absence of spouses and relatives, named heirs by the statute, the inheritance falls to the stepchildren of the testator. Fifthly, in the absence of spouses, relatives and children of the testator's spouse, named heirs by the statute, the inheritance falls to the municipality of the latest place of residence of the testator, as the

15 P. Lagarde, Présentation du règlement sur les successions, [in:] Droit européen des successions internationales. Le Règlement du 4 juillet 2012, G. Khairallah, M. Revillard (eds.), Paris 2013, pp. 5-16.

${ }^{16}$ Cf. G.A. Pelletier Jr, M.R. Sonnenreich, A Comparative Analysis of Civil Law Succession, "Villanova Law Review" 1966, No. 2, pp. 323-356. 
statutory heir. If the latest place of residence of the testator in the Republic of Poland cannot be determined or if the latest place of residence is located abroad, the inheritance falls to the State Treasury as the statutory heir ${ }^{17}$.

Such provisions surely protect the family. The circle of heirs is very broad, which is not often encountered in other systems. The blood ties, which form the basis for qualifying a person as an heir, are practically not limited by law. So, even the most distant relatives may be named heirs. A major role is also played by the spouse, whose position does not depend on the length of the marriage, but only on whether the marriage was valid at the time of the testator's death. Polish law provides for an interesting solution in that regard. Pursuant to Article 940 of the Civil Code, a spouse is excluded from succession if the testator applied for adjudicating a divorce or separation owing to the spouse's default, and the claim was justified ${ }^{18}$. Such exclusion of the spouse from succession takes place by virtue of a court decision. The exclusion may be claimed by any of the other statutory heirs named along with the spouse. The deadline for filing a petition in that regard is six months from the date on which the heir learns about the opening of the inheritance, but not later than within one year of the opening of the inheritance. This solution is related to another provision of the Polish law, in accordance with which the divorce or separation proceedings instigated by one of the spouses when the other spouse was alive, are discontinued if not completed before the death of one of the spouses (Article 446 of the Code of Civil Procedure). The fact that such proceedings are open at the time of the testator's death is not insignificant and may have an impact on the order of succession with regard to the deceased, despite the fact that formally the marriage existed at the moment of opening the inheritance. The legislator has foreseen a sanction in the form of the possibility of excluding a surviving spouse from succession, if the testator filed a petition for divorce or separation owing to the default of the surviving spouse, and

${ }_{17}$ Cf. M. Załucki, Krag spadkobierców ustawowych de lege lata $i$ de lege ferenda [The Circle of Statutory Heirs de lege lata and de lege ferenda], "Przegląd Sądowy" 2008, No. 1, pp. 94-105.

${ }^{18}$ L. Stecki, Wyłaczenie matżonka od dziedziczenia ustawowego (Art. 940 k.c.) [Exclusion of Spouse From Statutory Inheritance], "Ruch Prawniczy Ekonomiczny i Socjologiczny" 1990, No. 1, pp. 79-92. 
the petition was justified. The provision, thus, includes a departure from the principle expressed in Article 931.1 of the Civil Code, according to which naming a spouse an heir by the statute depends on the existence of a formal marriage with the testator at the time of the testator's death. The basis of the provisions of Article 940 of the Civil Code is the assumption that a spouse should be excluded from succession, if the spouse defaulted against the testator and would not inherit after the testator, but the adjudication of the divorce due to the spouse's default was prevented by the death of the testator. In such way, the moral aspect is introduced in the statutory succession, present practically in the whole succession law, just to mention the provisions which are applicable to unworthiness to inherit or to disinheritance.

The Polish statutory succession regulation is based on two basic foundations: relationship and marriage. It is a guarantee of leaving the estate in private hands, and may be assessed as one contributing to an extension of assets and mobilisation to gather the assets. Basically, although not without any reservations, the solution is based on the concept of the implied will of the testator. It is to express the hypothetical will of the deceased. The testator, knowing the statutory order of succession, may assume it to be compliant with their will and may intentionally refrain from drawing up a will ${ }^{19}$.

Also, in German law, statutory succession is mainly based on two underlying principles: relationship (Article 1924-1929 BGB) and marriage (Article 1931-1934 BGB) ${ }^{20}$. The order of statutory succession is oriented on the typical intent of the testator, reflected by the usual life situations with regard to the cases of inheritance. The system of succession provided for in German Civil Law states that first of all the spouse, and only later close relatives are named as heirs, which may mean that the German legislator focuses on the personal relationships between the testator and the heirs. Pursuant to the German Civil Code, the surviving spouse is entitled to one-quarter of the inheritance if there are heirs of the first order living and is entitled to one-half of the inheritance if there are heirs of the second order or grandparents living. Furthermore, when descendants of

${ }_{19}$ M. Załucki, Uniform European Inheritance Law. Myth, Dream or Reality of the Future, Kraków 2015, p. 58 et seq.

${ }^{20}$ H. Bartsch, M.B. Bartsch, Das aktuelle Erbrecht, Regensburg 2010, p. 16 et seq. 
a grandparent would take a share in accordance with the provisions of art. 1926 BGB, the surviving spouse will take that share. In the absence of heirs of the first or second order or the grandparents, the surviving spouse takes the entire inheritance (Art. 1931 BGB) ${ }^{21}$. The mentioned order of succession is determined in accordance with the heirs' blood ties with the deceased as follows: heirs of the first order comprise direct descendants of the deceased. A descendant who is living when succession occurs will exclude from the succession those descendants who are related to the deceased through them. If this descendant is no longer living at the time that the succession takes place, those descendants who are related to the deceased through them will take in their place (succession per stirpes) (Art. 1924 BGB). Children will take in equal measures. Heirs of the second order comprise the parents of the deceased and their descendants (brothers and sisters, including half-siblings, nephews and nieces, and their children). If the parents are alive when succession takes place, they alone will succeed in equal measures. If the father or the mother is no longer alive when succession takes place, their descendants will take in their place in accordance with the provisions applicable to the succession of heirs of the first order. If the deceased parent does not leave any descendants, the surviving parent alone will succeed (Art. $1925 B G B)^{22}$. Heirs of the third order comprise the grandparents of the deceased and their descendants (uncles and aunts, cousins, etc.). If the grandparents are alive when succession occurs, they alone will take in equal shares. (Art. 1926 BGB). Heirs of the fourth order comprise the great-grandparents of the deceased and their descendants (Art. 1928 $B G B)$. Heirs of the fifth order and of subsequent orders comprise more distant ancestors and their descendants (Art. 1929 BGB). In theory, the principle of blood-related succession continues infinitely from the closest to the most distant relative. However, from the fourth order onwards, the surviving spouse's (or civil partner's) right supersedes any right to inherit as a relative (Art. 1931 II $B G B)^{23}$.

${ }^{21}$ Cf. R. Zimmermann, Intestate Succession in Germany, [in:] Comparative Succession Law. Intestate Succession, K. G. C. Reid, M. J. de Wall, R. Zimmermann (eds.), Oxford 2015, passim.

${ }^{22}$ D. Olzen, Erbrecht, Berlin 2009, p. 40 et seq.

${ }^{23}$ Cf. D. Leipold, Erbrecht, Tübingen 2014, passim. 
As may be seen in the light of the above provisions, it is a rule that there are close personal contacts between the testators and the closest members of their families (spouses, children, grand-children, parents), from which also stems a specific duty to provide support. The personal relationship is also accompanied by an economic relationship. In most cases the testator had not independently arrived at the assets left: the spouse had also contributed to the origination of the assets either by cooperation, or by running their household, or by bringing up children. Also parents contribute to the economic development of their children by financial support, bringing up, or enabling education. In many cases, children support parents after they finish their education. These arguments - in the opinions of the commentators - had a decisive influence on the shape of statutory succession in Germany, and also in that context the freedom of bequeathing and the possible limitation thereof must be considered ${ }^{24}$. This shows that the German succession system focuses on protecting the family. The estate left by the testator, to the creation of which the closest persons had contributed, should - in principle - be left within the family and support the economic existence of the family members. However, there are voices in the German doctrine, which challenge the motives of such solutions and state that the social function of the succession law has changed in recent years, and, thus, the guideline of keeping the estate within the family is no longer valid and there may be departures from that basic thought. This could be supported, among other things, by allowing solutions in which statutory succession does not need to apply to the family of the testator. Although this has not yet been reflected within the German law in a new circle of statutory heirs, it must be mentioned that non-statutory succession based on a will or an inheritance agreement is very popular in Germany, and with regard to social needs, there is visible a liberalized approach of lawyers to any disposition of assets by a person for the event of their death. The argument is often indicated that currently the lifespan of a man is longer, compared to the time when $B G B$ was created, and, therefore, at the moment of the parent's death the descendants are usually financially independent of the parents and there is no need to

${ }^{24}$ R. Zimmermann, Intestate Succession ..., supra note 21. 
protect their interest by an extensive system of legitim or other benefits (e.g. alimony) for the necessary heirs ${ }^{25}$. Therefore, a trend may currently be observed towards the interpretation of the binding provisions from the angle of higher freedom in bequeathing. This has been expressed, among other things, in the view of the Federal Constitutional Tribunal set out in the decision of 19 April 2005 (in the joint cases 1 BvR 1644/00 and $1 \mathrm{BvR} 188 / 03)^{26}$, where it was proved that legitim is not subject to constitutional protection, and the legislator shall decide whether such institution is to be maintained within the binding regulations. This is important for statutory succession because it justifies the treatment of legitim rather as a supplementary solution with regard to bequeathing in the form of a will, and not the other way round.

In other German-speaking countries, the principles of statutory succession are slightly different. In Austria there is a parental system of statutory succession (Article 731 and subsequent of AGBG), which means that the potential heirs are divided into four succession groups: a) children of the testator and their descendants within the first group; 2) parents of the testator and their descendants within the second group; 3) grand-parents and their descendants within the third group; 4) great grand-parents within the fourth group ${ }^{27}$. The heirs of the particular succession groups are named in the subsequent order ("one after the other"). Thus, the closer group excludes the share of the further one. The succession right of a spouse is co-existent with the right of the relatives (Art. $744 \mathrm{ABGB})^{28}$. The share of a spouse in the inheritance depends on the succession group with which the succession co-existence occurs. If the spouse inherits the estate along with the children of the testator and their descendants, the share of the spouse is $1 / 3$. If the spouse inherits

${ }^{25}$ G. Schiemann, Die Renaissance des Erbrechts, Zeitschrift für Erbrecht und Vermögensnachfolge 1995, pp. 197-201.

${ }^{26}$ Cf. http://www.dejure.org/, [last accessed: 15.12.2017].

27 S. Ferrari, Familienerbrecht und Testierfreiheit in Österreich, [in:] Familienerbrecht und Testierfreiheit im europäischen Vergleich, D. Henrich, D. Schwab (eds.), Bielefeld 2001, p. 174.

${ }^{28}$ S. Kalls, Ch. Klampfl, Das neue Erbrecht nach der Reform - eine Übersicht zur Überprüfung Ihrer Vermögensnachfolgeplanung, Journal für Erbrecht und Vermögensnachfolge 2017, No. 4, pp. 152-158. 
the estate along with the parents of the testator and their descendants, the spouse receives $2 / 3^{29}$.

Also in Switzerland, which is not a member of the European Union, but its Civil Code is a frequent point of reference in comparative legal studies, the sequence of succession is based on the family right to inheritance, assuming that "family" means also children born outside of marriages and adopted children as well as their descendants ${ }^{30}$. At the moment when the cantonal succession regulations were replaced by ZGB, the legislator had to choose between the law binding mainly in the western cantons of Switzerland, based on the class system, and the parental system popular in the German-speaking part of the country. In ZGB the parental system has been selected. Thus, three succession groups were separated: 1 ) descendants of the testator within the first group; 2 ) parents of the testators and their descendants within the second group; 3) grand-parents of the testator and their descendants within the third group. Any person from a further group may become statutory heir, provided that none of the persons of the closer group is an heir, whereas the spouse is entitled to inheritance along with the persons of the respective group ${ }^{31}$. The share of the spouse depends on the succession group (Article $462 \mathrm{ZGB}$ ). In a situation when the testator has no living spouse or relatives entitled to inheritance, the estate is transferred to the canton in which the testator had their latest place of residence, or to the municipality, which by law of the respective canton will be determined as authorized to receive the estate (Art. 466 ZGB). The above principles have been binding since 1988, when ZGB was updated as regards succession. With regard to that regulation, the Swiss doctrine draws attention to the fact that the intent of the legislator was to maximally favour the surviving spouse in reference to the other statutory successors, which was supposed to reflect the expectations of the society ${ }^{32}$.

29 Austrian law has recently been reformed in this area. Cf. P. Barth, U. Psesndorfer, Erbrechtsreform 2015, Wien 2015, p. 1 et seq.

${ }^{30}$ J. Appel, U. Appel, International Vererben, Norderstedt 2011, p. 166 et seq.

${ }^{31}$ Cf. H. Christensen III, International Estate Planning, New York 2012, ch. 17.

${ }^{32}$ Switzerland also has plans for reform Cf. https:// www.bj.admin.ch/bj/de/home/ gesellschaft/gesetzgebung/erbrecht.html, [last accessed: 15.12.2017]. 
Particularly interesting are also the rules of statutory succession comprised in the Dutch law. That law refers to relationship and marriage as the ties contributing to statutory succession. There are four succession groups: 1) the spouse and children of the deceased; 2) parents and siblings; 3) grand-parents; 4) great grand-parents. The descendants of a child are named based on the representation principle, whereas a relative of the deceased in a degree higher than sixth is not a statutory heir (Article 4:10 of the Dutch Civil Code $)^{33}$. In the absence of statutory heirs the estate falls to the state, which is not, however, treated as an heir (Article 4:189, in relation to Article 226 of the Dutch Civil Code). As regards the first group, if there is no will, the surviving spouse and children of the deceased inherit in equal shares. In order to protect the surviving spouse, the law stipulates that the entire estate goes to the surviving spouse and that the children have a monetary claim equalling their statutory share (statutory distribution). However, in certain circumstances there is the possibility of exercising a right (wilsrecht) by which the child may ask for their share in the property of the estate ${ }^{34}$.

In English law (England and Wales) the system of statutory succession slightly differs from the solution of continental Europe. Intestate succession is governed by the Administration of Estates Act 1925 as amended. According to that Act (Art. 46) where a person dies in England \& Wales leaving a surviving spouse, but no issue, parents, or siblings, the spouse or civil partner inherits the estate in its entirety ${ }^{35}$. Where there is a surviving spouse and issue, the spouse takes the personal chattels, plus the first $£ 250,000$ and a life interest in half of the remainder. The Intestate's issue take half the residue of the estate immediately and the other half on the death of the surviving spouse or civil partner (retaining an interest in this second half in the interim). If there is no issue, but

${ }^{33}$ See more broadly: M. Pazdan, Polsko-holenderska wymiana pogląów na temat prawa spadkowego [Polish-Dutch Exchange of Views on Succession Law], “Rejent” 2006, No. 2, p. 13 et seq.

${ }^{34}$ Cf. B.E. Reinhartz, Recent Changes in the Law of Succession in the Netherlands: On the Road Towards a European Law of Succession?, "Electronic Journal of Comparative Law" 2007, No. 1, pp. 1-18; P.H.M. Gerver, Het nieuwe erfrecht ingevoerd, Nederlands Juristenblad 2003, No. 2, pp. 72-76.

${ }^{35}$ F. Burns, Surviving Spouses, Surviving Children and the Reform of Total Intestacy Law in England and Scotland: Past, Present and Future, "Legal Studies" 2013, No. 1, pp. 85-118. 
the Intestate's parents or siblings survive, the spouse or civil partner takes the first $£ 450,000$ plus half of the remainder. The rest passes to the parents absolutely or, if both have predeceased, to the siblings of the whole blood (or, if predeceased, their issue). If the estate falls below the above-mentioned limits, it passes in whole to the spouse. If there is no spouse surviving, the estate passes to the Intestate's issue per stirpes. If there is no issue, the parents benefit. If there are no surviving heirs in these classes of kin, the estate passes to the first of the following classes of kin which contains someone alive (or who survived the Intestate): siblings of the whole blood or their issue per stirpes, siblings of the half blood or their issue per stirpes, grandparents per capita, uncles and aunts of the whole blood or their issue per stirpes, uncles and aunts of the half blood or their issue per stirpes. If there are no survivors in any of these classes, the estate passes to the Crown ${ }^{36}$.

Undoubtedly, the role of a marriage seems to be very important in that system. However, referring to the English law, it must be mentioned that in the common law systems the construction of a trust is often applied to the estate of the deceased. It is an institution characteristic to the Anglo-Saxon countries, which has no equivalent in the systems of enacted law, being a sort of holding legal relationship. According to the classical definition, a trust is the commitment of the trustee to deal with an entrusted property, separated from the trustee's private property, of which the trustee is the nominal owner for the good of beneficiaries (other people or the trustee himself), who have the right to claim the execution of the trusteeship commitment, or to deal with the entrusted property for the purpose of performance of a specific objective. A trust may originate by virtue of a legal act or ex lege, whereas trusts established mortis causa are of major importance for succession law.

\section{STATUTORY INHERITANCE AND DOUBTS}

Similar solutions related to the circle of statutory successors and the order of succession, differing to a minor or major extent from those mentioned

${ }^{36}$ R. Probert, M. Harding, England and Wales, [in:] International Encyclopaedia for Family and Succession Law, W. Pintens (ed.), Kluwer Law Online 2016, pp. 202-257. 
above, are binding in the other countries of the European Union ${ }^{37}$. As may be expected, the image reflected upon the presentation of the selected legal regulations - despite the apparent differences in the particular solutions - has not changed in reference to the initial assumptions made. Each of the solutions protects the legal and family relationships of the testator in a manner proper to the respective legislation. The circle of heirs and the order of their naming \{as?\} heirs depend on the concept assumed by the given system and generally express the traditions of the particular countries ${ }^{38}$. Applying the solutions in practice, specifically with reference to the Succession Regulation No. 650/2012 post 17 August 2015, may often mean that the citizens of other countries may be surprised at the legal succession solution. Although the differences are not significant, the absence of a given person within the circle of statutory heirs in another legal system or the order of naming heirs may be surprising. Thus, citizens may lose trust in the law. If, for example, pursuant to the Polish law being the domestic law of the deceased, the statutory succession would fall to stepchildren, but the deceased had a habitual place of residence in Germany, the persons will not inherit by statute, as the German law - applicable based on the rule of the latest habitual place of residence of the testator - does not include such a category of persons within the circle of those entitled to inheritance. There will, of course, be more such cases against the background of the specific domestic regulations, which refer, for example, to registered partner relations that are not recognized by some EU countries. The domestic discrepancies and the consequences thereof, as a result of applying the provisions of the Regulation, seem to be a major defect. The potential heirs based on their domestic law, may lose the status of an heir when the succession case is of a trans-border nature. This is not a satisfactory effect of applying the Regulation and, as it may be expected, it will open a path to claims for indemnification of losses, as depriving a person of the succession benefits vested in that person by their domestic law may be perceived as a loss.

${ }^{37}$ Cf. M. Załucki, supra note 19.

${ }^{38}$ See also: D. Reid, From the Cradle to the Grave: Politics, Families and Inheritance Law, “Edingurgh Law Review" 2008, No. 3, pp. 391-417. 
On the other hand, the existing differences may contribute to the achievement of interesting results during the estate planning process and enable the avoidance of domestic regulations in compliance with the law. This happens just because some legal succession rights of a specific category of persons depend on their right to inheritance as statutory successors. If, based on a foreign law, which will apply in compliance with the provisions of Regulation No. 650/2012, the respective person is not an heir, he/she will not be entitled to any benefits related to that status. For example, the Polish doctrine indicates that the application of the provisions of Regulation No. 650/2012 is to some extent a method to avoid the provisions regarding legitim. It must be reminded that the concept of protecting the persons closest to the testator is provided in Article 991 of the Polish Civil Code, which assumes that the descendants, the spouse, and the parents of the testator, who would be named heirs by statute, are entitled - if the entitled person is permanently unable to work or if the entitled descendant is of minor age - to two thirds of the inheritance, which would fall to them by statutory succession, and in other cases to half of the share (legitim). If the entitled person fails to receive the legitim vesting in them, either in the form of donation by the testator, or in the form of being named an heir, or in the form of a will, the person may claim against the heir the payment of an amount needed to cover the legitim or supplementation of the legitim. The regulation is based on the indisputable axiom that the testator cannot, by virtue of their disposition, exclude or limit that protection ${ }^{39}$. Meanwhile, the provisions of the Regulation No. 650/2012 represent a major departure from that principle. The testator may, thus, lead to a change of the type and scope of protection of the closest persons, for example by not selecting the domestic law, in which case the applicable law will be the foreign and not the Polish law. In certain situations, even the complete exclusion of the protection of persons close to the testator is possible in some cases. As an example, if the place of habitual residence of the testator is the Netherlands, in the light of the Dutch regulation, only the descendants of the testator are entitled to the legitim (Article 4:63.2 of the Dutch Civil Code). If the law applicable to succession is to be the Dutch law, then

${ }^{39}$ Cf. P. Księżak, Zachowek w polskim prawie spadkowym [Legitim in Polish Inheritance Law], Warszawa 2012, p. 103 et seq. 
other persons entitled to legitim pursuant to the Polish law will not get the legitim. This is a controversial solution, particularly with regard to the fact that the place of habitual residence outside Poland now applies to a large number of Poles (some statistics refer even to several million people), possibly making such selections with regard to succession become very popular in the future ${ }^{40}$. This obviously refers also to the citizens of other EU countries, as many of them are residing or working in countries other than their mother countries. On that background, the provisions of the Regulation may become basis for many disputes and misunderstandings in the future.

\section{FINAL REMARKS}

From that angle, the provisions of Regulation No. 650/2012 seem to create new problems in the context of statutory succession, which have not been present so far to such a broad extent. The EU legislator, introducing solely a uniform regulation with regard to private international law, should have expected that this would raise certain controversies for the (domestic) substantive succession law, particularly in practice. Even though the Regulation is a step forward, solving a lot of problems of the international succession law, it brings about dilemmas which have not existed so far. This will have to result, and already results in a series of misunderstandings, which cannot be avoided against the background of differing domestic solutions. Perhaps these misunderstandings will become a stimulus to undertake further works on succession law unification, but this time with regard to uniform substantive law regulations, so that there are no such discrepancies and possibilities of abuse in the future. After all the succession law should contribute to strengthening family relationships instead of breaking them.

${ }^{40}$ See also M. Załucki, Disinheritance Against The EU Regulation on Succession (No. 650/2012). Polish Law Perspective, "European Journal of Economics, Law and Politics" 2017, No. 2, pp. 16-33. 
